Jourval of

Epidemiology and Community Health, 1979, 33, 84-90

\title{
The influence of a premarital conception and various obstetric complications on subsequent prenatal health behaviour
}

\author{
JOHN B. McKINLAY \\ From the Department of Sociology, University of Boston, and the Massachusetts General Hospital, Boston
}

SONJA M. McKINLAY

From the Department of Mathematics, University of Boston, and the Radcliffe Institute, Harvard University

SUMMARY This paper is a companion to an earlier report on prenatal visiting patterns in Aberdeen, Scotland (McKinlay, 1970). It examines the following three main questions: (1) Is the emerging trend towards later maternity care among young nulliparae largely due to those who delay because of premarital conception? (2) If premarital conception is primarily responsible for this trend, is this pattern of visiting behaviour continued in subsequent pregnancies, and what variation is there in such behaviour-between, for example, different socioeconomic groups and age groups? (3) Does the presence of one or more obstetric complications associated with a first pregnancy or birth have an effect on subsequent prenatal health behaviour, and does this effect, if present, interact with, say, socioeconomic status, or the legal status of the first pregnancy? The paper concludes with a discussion of some policy implications of the findings.

In an earlier study (McKinlay, 1970) of the utilisation of maternity care in Aberdeen during the period 1951 to 1966 , it was found that (a) women in lower socioeconomic categories showed a trend towards earlier visiting, although (b) the grand multiparae of the lowest social category, known as the 'hard core' of parity three or more, still began prenatal care much later than any other group, and (c) young nulliparae, especially those under 20 , began to come noticeably later for care in this period. On the assumption, at present unsupported, that prenatal care is effective and does influence either infant or maternal mortality and morbidity, the apparent decline in prenatal care among young primigravidae during the period of the initial study may be considered a cause for concern and for further investigation.

\section{Methods}

The women included in this study were selected from maternity hospital records in the city of Aberdeen, Scotland, according to the following criteria:

(1) Married women who bore their first child in Aberdeen in the 10-year period 1951-1960, and for whom this birth was recorded by the staff of the Aberdeen Maternity Hospital (2) Women defined by the first criterion who had also had the results of at least two further consecutive pregnancies entered in the same records and (3) Women whose records of all three pregnancies and outcomes were substantially complete. For a fuller description of the study population see McKinlay (1970).

Additional criteria were then employed to separate those identified through this initial selection into two groups of cases and controls representing extremes on a continuum. Women were eligible as controls if they had experienced at least three live births with none of the following complications recorded: stillbirth, neonatal death, low-birthweight (birth outcome), forceps delivery, long labour, caesarean section, or prenatal hospitalisation (pregnancy and labour).

Women were assigned to case groups on an hierarchical basis depending on their experience, during the first pregnancy, of one or more of the seven events or complications isolated. For example, a woman giving birth after a long labour to a lowbirthweight baby which subsequently died within a few days would be assigned to the 'neonatal death' group, because this complication can reasonably be considered to supersede the others. Spontaneous abortion during the first pregnancy was omitted as a possible complication because those experiencing 
fetal loss during the first pregnancy were known to be more likely to experience subsequent abortions, resulting in incomplete data on prenatal visiting, and a severe reduction in the number of cases available for analysis.

An important point about the subjects selected for study is the fact that they have all had at least three pregnancies. Apart from any other differences, this means that the groups investigated in this study will be of lower socioeconomic status than the married childbearing population as a whole. Indeed, of the control groups (of parity three or more), it was found that about $40 \%$ had husbands in semiskilled or unskilled occupations, compared with about $27 \%$ of the general, married, childbearing population during the same period. As a result of this selectivity, inferences are restricted to those women who experienced three or more pregnancies.

The incompleteness of prenatal visiting information added a further restriction, particularly in the selection of the case group. Only those women were included for whom the week of the first visit was recorded for the first and at least one of the subsequent two pregnancies. This restriction depleted the randomly selected 1000 initial controls (100 from each year) to a total of 902 , and halved some case groups, which included total or near-total populations.

Although these data may appear somewhat outdated, two points should be made. Firstly, the sampling period (1951-1960) had to be early enough to ensure that those women delivering their first child in 1960 would have enough time for two subsequent pregnancies. In other words, although the sampling period was 1951-1960, the actual period covered by this study was 1951-1969 (1969 was the latest year for which complete data were available, when the records were sampled). Secondly, these data are unique, and their presentation and analysis here will, it is hoped, stimulate interest in establishing similar record systems elsewhere-perhaps in relation to other areas of medical care.

\section{Results}

The following analysis is divided into two main sections-firstly, a description of the study groups with respect to several relevant variables, and, secondly, comparisons from which a number of inferences can be drawn.

\section{DESCRIPTION}

\section{(i) Social class and the legal status of the first pregnancy}

The first two questions outlined in the summary concern the possible effect of a premarital conception (PMC) on subsequent prenatal behaviour. The data were divided into two groups according to the legal status of the first conception by comparing the date of delivery with the date of marriage. (In doubtful cases, the length of gestation was available to confirm a classification). The legal status of the first conception was then crosstabulated with socioeconomic status, as defined by the Registrar General's classifications of social class. The non-manual groups were combined because of their very small numbers, the similar proportions of premaritally conceived (PMC) births, and the similar age distributions of the mothers at first birth in these groups.

The resulting joint distribution of socioeconomic status and legal status of first pregnancy is presented in Table 1 for the controls (all years combined) and for the complication groups (divided into two sets). The controls show a preponderance of women $(34 \%)$ married to skilled manual workers. Within each of the four socioeconomic groups, the proportion of PMCs increased from slightly less than one-quarter of the births in the non-manual groups to $43 \%$ in the unskilled group. When the five cohorts were examined separately, deviations between them were small enough for them to be validly combined for all analyses in this paper.

For the complication groups, the overall joint distribution of these two variables is similar to that for the combined controls. However, it is clear that

Table 1 The percentage of premarital conceptions in each socioeconomic group, for two sets of complications and controls

\begin{tabular}{|c|c|c|c|c|c|c|c|c|c|}
\hline \multirow{3}{*}{$\begin{array}{l}\text { Socioeconomic } \\
\text { group }\end{array}$} & \multicolumn{3}{|c|}{ COMPLICATIONS } & & & & \multicolumn{3}{|c|}{ CONTROLS } \\
\hline & \multicolumn{2}{|c|}{ Birth and outcome } & \multirow[b]{2}{*}{$\%(P M C) *$} & \multicolumn{3}{|c|}{ Pregnancy and labour } & \multicolumn{2}{|c|}{ (All years) } & \multirow[b]{2}{*}{$\%(P M C)$} \\
\hline & $\begin{array}{l}\text { No. in } \\
\text { group }\end{array}$ & Per cent & & $\begin{array}{l}\text { No. in } \\
\text { group }\end{array}$ & Per cent & $\%(P M C)$ & $\begin{array}{l}\text { No. in } \\
\text { group }\end{array}$ & Per cent & \\
\hline $\begin{array}{l}\text { Non-manual } \\
\text { Skilled manual } \\
\text { Semi-skilled manual } \\
\text { Unskilled manual } \\
\text { Total }\end{array}$ & $\begin{array}{r}50 \\
59 \\
59 \\
45 \\
213\end{array}$ & $\begin{array}{r}23 \cdot 5 \\
27 \cdot 7 \\
27 \cdot 7 \\
21 \cdot 1 \\
100 \cdot 0\end{array}$ & $\begin{array}{l}22 \cdot 0 \\
47 \cdot 4 \\
54 \cdot 2 \\
53 \cdot 3 \\
-\end{array}$ & $\begin{array}{r}70 \\
131 \\
74 \\
64 \\
339\end{array}$ & $\begin{array}{r}20 \cdot 6 \\
38 \cdot 7 \\
21 \cdot 8 \\
18 \cdot 9 \\
100 \cdot 0\end{array}$ & $\begin{array}{l}17 \cdot 1 \\
26 \cdot 0 \\
37 \cdot 8 \\
37 \cdot 5 \\
-\end{array}$ & $\begin{array}{l}179 \\
352 \\
230 \\
141 \\
902\end{array}$ & $\begin{array}{r}19.9 \\
39.0 \\
25.5 \\
15.6 \\
100.0\end{array}$ & $\begin{array}{l}23 \cdot 5 \\
29 \cdot 8 \\
32 \cdot 2 \\
43 \cdot 3 \\
-\end{array}$ \\
\hline
\end{tabular}

*\%(PMC) is calculated as the percentage of premarital conceptions in each socioeconomic group. The denominator is the number in each group. For example, $22.0 \%$ PMC (non-manual, birth outcome complication) $=\left(\frac{1}{5} \frac{1}{6} \times 100 \%\right)$. 
the two sets of complications (pertaining to birth outcome and pregnancy/delivery respectively) have different distributions. The first set, the more severe complications of birth outcome, appears to have a slight excess in the semi- and unskilled groups ( $28 \%$ and $22 \%$ respectively, compared with $24 \%$ and $20 \%$ overall). The second set has an excess in the skilled group (39\% compared with $34 \%$ overall). In all social classifications, there is an excess of PMCs in the complications of birth outcome. These differences probably reflect the markedly different age distributions for PMC and legitimate conceptions which are described below, as well as the socioeconomic differences already mentioned. Young adolescent women from low socioeconomic strata have a poorer diet, among other factors, so they are more likely to produce babies in poor condition. This phenomenon has already been well documented (Illsley, 1956a; Butler and Bonham, 1963; MacMahon et al., 1972). On the other hand, older women of higher socioeconomic status having a first baby are more likely to experience difficulties during pregnancy and labour, although the baby is likely to be healthy (Gill et al., 1970).

\section{(ii) Age at first birth}

For women with legitimate pregnancies, the mean ages ranged from about 24 in the non-manual to 21 in the unskilled group, with standard deviations of about three years. Women with PMCs were consistently younger on average. Their mean ages ranged from about 22 in the non-manual to 19 in the unskilled group, with standard deviations of between one and two and a half years (where numbers permitted a reliable estimate). These differences in age distribution were remarkably consistent across all complication and control groups; and, given the close relationship between age, socioeconomic classification, and legal status at first conception, it was considered that age would be unlikely to be a major source of bias in subsequent comparisons, provided account was taken of the other two variables. Moreover, within the groups defined according to status at first conception, age consistently showed very low correlations with the week of the first prenatal visit, indicating that covariance adjustment would have little effect on the estimates of the mean week of the first visit.

\section{COMPARISONS}

(i) The effect of PMC on week of first visit for first pregnancy

The first question posed here, as a consequence of the analysis in the previous paper, is whether the recent trend towards later care among young nulliparae is due to a preponderance of premarital conceptions. To provide an answer, the mean week of the first prenatal visit was calculated separately for PMCs and legitimate conceptions. These means (and standard errors) are summarised in Table 2.

For legitimate conceptions, the mean week of the first visit varied about the fifteenth week of gestation, with an indication that wives of semiand unskilled manual workers began visiting slightly later. For the controls, $95 \%$ confidence limits within each socio-economic group are at most (mean \pm 0.9 weeks). Although the complication groups were too small for separate confidence intervals to be estimated, it is clear that the overall means are comparable to those for the control group. In other words, given that the complication had not yet occurred, there seemed to be no intrinsic difference in prenatal visiting behaviour during the first pregnancy between those with and those without complications. The PMC group had a mean week of first visit estimated to be

Table 2 Mean week of first visit for each of two groups of complications and the control group, by socioeconomic status and status of the first conception

\begin{tabular}{|c|c|c|c|c|c|c|c|}
\hline \multirow[b]{2}{*}{$\begin{array}{l}\text { Socioeconomic } \\
\text { group }\end{array}$} & & \multicolumn{2}{|c|}{$\begin{array}{l}\text { BIRTH OUTCOME } \\
\text { COMPLICATION }\end{array}$} & \multicolumn{2}{|c|}{$\begin{array}{l}\text { PREGNANCY AND LABOUR } \\
\text { COMPLICATION }\end{array}$} & \multirow{2}{*}{$\frac{\text { CONTROLS }}{\begin{array}{l}\text { All years) } \\
\text { Postmarital } \\
\text { conception }\end{array}}$} & \multirow[b]{2}{*}{$\begin{array}{l}\text { Premarital } \\
\text { conception }\end{array}$} \\
\hline & & $\begin{array}{l}\text { Postmarital } \\
\text { conception }\end{array}$ & $\begin{array}{l}\text { Premarital } \\
\text { conception }\end{array}$ & $\begin{array}{l}\text { Postmarital } \\
\text { conception }\end{array}$ & $\begin{array}{l}\text { Premarital } \\
\text { conception }\end{array}$ & & \\
\hline $\begin{array}{l}\text { Non-manual } \\
\text { Skilled manual } \\
\text { Semi-skilled manual } \\
\text { Unskilled manual } \\
\text { All socioeconomic groups } \\
\text { Week of first visit not stated }\end{array}$ & $\begin{array}{l}\text { No. } \\
\text { Mean } \\
\text { No. } \\
\text { Mean } \\
\text { No. } \\
\text { Mean } \\
\text { No. } \\
\text { Mean } \\
\text { No. } \\
\text { Mean } \\
\text { SE* }\end{array}$ & $\begin{array}{l}35 \\
14 \cdot 7 \\
31 \\
13 \cdot 3 \\
26 \\
16 \cdot 6 \\
21 \\
15 \cdot 5 \\
113 \\
15 \cdot 0 \\
0 \cdot 76 \\
5\end{array}$ & $\begin{array}{l}8 \\
18 \cdot 2 \\
23 \\
18 \cdot 7 \\
22 \\
19 \cdot 9 \\
19 \\
18 \cdot 2 \\
72 \cdot 2 \\
18 \cdot 9 \\
1 \cdot 10 \\
23\end{array}$ & $\begin{array}{l}52 \\
14 \cdot 6 \\
88 \\
14 \cdot 1 \\
43 \\
14 \cdot 2 \\
33 \\
15 \cdot 8 \\
216 \\
14 \cdot 5 \\
0 \cdot 59 \\
25\end{array}$ & $\begin{array}{l}9 \\
22 \cdot 2 \\
28 \\
19 \cdot 9 \\
20 \\
19 \cdot 9 \\
17 \\
21 \cdot 4 \\
74 \\
20 \cdot 5 \\
1 \cdot 50 \\
24\end{array}$ & $\begin{array}{l}136 \\
14 \cdot 7 \\
247 \\
14 \cdot 3 \\
156 \\
15 \cdot 6 \\
80 \\
15 \cdot 2 \\
619 \\
14 \cdot 8 \\
0 \cdot 18 \\
1\end{array}$ & $\begin{array}{l}42 \\
21 \cdot 6 \\
105 \\
20 \cdot 1 \\
74 \\
20 \cdot 5 \\
61 \\
20 \cdot 1 \\
282 \\
20 \cdot 4 \\
0 \cdot 33 \\
0\end{array}$ \\
\hline
\end{tabular}

*SE is the estimated standard error of the sample mean, defined as $\left[\frac{\Sigma(x-\bar{x})^{2}}{n(n-1)}\right]^{\frac{1}{2}}$ for this and subsequent Tables. 
about five weeks later than those with legitimate conceptions, which is consistent with earlier findings (Illsley, 1956b). The $95 \%$ confidence limits within each socio-economic group for controls were at most $( \pm 1.6$ weeks), with the mean in all cases more than 20 weeks. Again, there appeared to be no consistent difference in the mean week of first visit between complication groups.

These data were re-analysed to give the percentage distribution over three categories of the week of the first visit as defined in the previous paper. Table 3 presents this distribution, which tends to be compare groups. The reduced numbers are due to abortions in the second and third pregnancies.

Means and standard errors for $\mathbf{D}_{12}$ are presented in Table 4. In presenting means, the semi- and unskilled manual groups were combined because of the small numbers. Standard errors of the means are given only for all socioeconomic groups combined. Beginning with postmarital conceptions, it is clear from the control group that women experiencing no complication associated with the first pregnancy tended to come approximately three weeks later on average for their first visit

Table 3 Percentage distribution of the week of first prenatal visit by status of first conception, for complication groups and controls

\begin{tabular}{|c|c|c|c|c|c|c|c|c|c|}
\hline \multirow[b]{2}{*}{ Week of first visit } & \multicolumn{3}{|c|}{ BIRTH OUTCOME COMPLICATION } & \multicolumn{5}{|c|}{ PREGNANCY AND LABOUR COMPLICATION } & \multirow{2}{*}{$\frac{\text { CONTROLS }}{\text { (All years) }}$} \\
\hline & Stillbirth & $\begin{array}{l}\text { Neonatal } \\
\text { death }\end{array}$ & $\begin{array}{l}\text { Low birth } \\
\text { weight }\end{array}$ & $\begin{array}{l}\text { Caesarean } \\
\text { section }\end{array}$ & $\begin{array}{l}\text { Forceps } \\
\text { delivery }\end{array}$ & $\begin{array}{l}\text { Long } \\
\text { labour }\end{array}$ & $\begin{array}{l}\text { Prenatal } \\
\text { hospital- } \\
\text { isation }\end{array}$ & Total & \\
\hline \multicolumn{10}{|l|}{$\begin{array}{l}\text { POSTMARITAL } \\
\text { CONCEPTION }\end{array}$} \\
\hline $\begin{array}{l}<17 \\
17-28 \\
>28 \\
\text { Total }(100 \%) \\
\text { Not stated }\end{array}$ & $\begin{array}{c}67 \cdot 4 \\
30 \cdot 2 \\
2 \cdot 3 \\
40 \\
3\end{array}$ & $\begin{array}{c}66 \cdot 7 \\
33 \cdot 3 \\
0 \cdot 0 \\
30 \\
1\end{array}$ & $\begin{array}{c}65 \cdot 1 \\
32 \cdot 6 \\
2 \cdot 3 \\
42 \\
2\end{array}$ & $\begin{array}{c}78 \cdot 0 \\
20 \cdot 0 \\
2 \cdot 0 \\
50 \\
3\end{array}$ & $\begin{array}{l}82 \cdot 9 \\
15 \cdot 8 \\
1 \cdot 3 \\
76 \\
9\end{array}$ & $\begin{array}{c}80 \cdot 4 \\
15 \cdot 2 \\
4 \cdot 3 \\
46 \\
6\end{array}$ & $\begin{array}{c}71 \cdot 7 \\
28 \cdot 3 \\
0 \cdot 0 \\
46 \\
5\end{array}$ & $\begin{array}{c}74 \cdot 6 \\
23 \cdot 7 \\
1 \cdot 8 \\
334 \\
31\end{array}$ & $\begin{array}{c}72 \cdot 7 \\
25 \cdot 5 \\
1 \cdot 8 \\
619 \\
1\end{array}$ \\
\hline \multicolumn{10}{|l|}{$\begin{array}{l}\text { PREMARITAL } \\
\text { CONCEPTION }\end{array}$} \\
\hline $\begin{array}{l}<17 \\
17-28 \\
>28 \\
\text { Total }(100 \%) \\
\text { Not stated }\end{array}$ & $\begin{array}{c}25 \cdot 0 \\
70 \cdot 8 \\
4 \cdot 2 \\
24 \\
5\end{array}$ & $\begin{array}{c}33 \cdot 3 \\
61 \cdot 9 \\
4 \cdot 8 \\
21 \\
5\end{array}$ & $\begin{array}{l}40 \cdot 7 \\
51 \cdot 9 \\
7 \cdot 4 \\
27 \\
13\end{array}$ & $\begin{array}{c}35 \cdot 7 \\
64 \cdot 3 \\
0 \cdot 0 \\
14 \\
3\end{array}$ & $\begin{array}{r}5 \cdot 0 \\
75 \cdot 0 \\
20.0 \\
20 \\
6\end{array}$ & $\begin{array}{c}26 \cdot 3 \\
68 \cdot 4 \\
5 \cdot 3 \\
19 \\
7\end{array}$ & $\begin{array}{c}27 \cdot 3 \\
63 \cdot 6 \\
9 \cdot 1 \\
22 \\
7\end{array}$ & $\begin{array}{c}27 \cdot 9 \\
64 \cdot 6 \\
7 \cdot 5 \\
147 \\
47\end{array}$ & $\begin{array}{c}23 \cdot 8 \\
68 \cdot 8 \\
7 \cdot 4 \\
282 \\
0\end{array}$ \\
\hline
\end{tabular}

positively skewed. The socioeconomic classification has been ignored for the sake of clarity, although the same differences in the distribution of the week of the first visit between social groups were observed consistently in these data just as they were in the previous study (McKinlay, 1970). The effect of conception status on the distribution of the week of the first visit is very clear in this Table.

\section{(ii) The effect of PMC and complications of the first pregnancy on subsequent prenatal care}

The next question is whether this difference described in (i) and/or the occurrence of complications affected subsequent prenatal visiting behaviour. Differences in the week of the first visit were calculated, for each woman, between subsequent pregnancies. The first difference $D_{12}$ was defined as the week of the first visit for the second pregnancy, minus the week of the first visit for the first pregnancy. A positive difference, therefore, indicates later visiting for the second pregnancy and a negative difference indicates earlier visiting. The difference $D_{23}$ was similarly defined for the second and third pregnancies. Means and standard errors for these differences were then used to in the second pregnancy. There is also a clear difference between wives of manual and non-manual workers, the latter beginning care two weeks later and the former beginning nearly four weeks later. In the complication groups, wives of manual workers again tended to come for care later than the non-manual group during the second pregnancy, although the trend is not so clear because of small numbers and considerable variability.

All complication groups tended to begin care earlier than the controls for the second pregnancy. In particular, the stillbirth and hospitalised groups showed no difference in the time of the first visit during the second pregnancy compared with the first pregnancy; the neonatal death group began care three weeks earlier during the second pregnancy compared with the first. It is noteworthy that, although numbers are small, most of the contribution to these small or negative differences came from the non-manual and skilled manual groups. This could imply that the shock of a stillbirth, neonatal death, or prenatal hospitalisation would be more likely to affect subsequent visiting behaviour among wives of non-manual or skilled manual workers. The marked effect of a neonatal 
Table 4 Mean difference* between weeks of first visit for first and second pregnancies, for complication and control groups by socioeconomic status, and status of the first conception

\begin{tabular}{|c|c|c|c|c|c|c|c|c|c|c|c|c|c|c|c|c|}
\hline \multirow{3}{*}{$\begin{array}{l}\text { Socioeconomic } \\
\text { group }\end{array}$} & \multicolumn{6}{|c|}{ BIRTH OUTCOME COMPLICATION } & \multicolumn{7}{|c|}{ PREGNANCY AND LABOUR COMPLICATION } & & \multirow{2}{*}{\multicolumn{2}{|c|}{$\frac{\text { CONTROLS }}{\text { (All years) }}$}} \\
\hline & \multicolumn{2}{|c|}{ Stillbirth } & \multicolumn{2}{|c|}{$\begin{array}{l}\text { Neonatal } \\
\text { death }\end{array}$} & \multicolumn{2}{|c|}{$\begin{array}{l}\text { Low birth } \\
\text { weight }\end{array}$} & \multicolumn{2}{|c|}{$\begin{array}{l}\text { Caesarean } \\
\text { section }\end{array}$} & \multicolumn{2}{|c|}{$\begin{array}{l}\text { Forceps } \\
\text { delivery }\end{array}$} & \multicolumn{2}{|c|}{ Long labour } & \multicolumn{2}{|c|}{$\begin{array}{l}\text { Prenatal } \\
\text { hospitalisation }\end{array}$} & & \\
\hline & No. & Mean & No. & Mean & No. & Mean & No. & Mean & No. & Mean & No. & Mean & No. & Mean & No. & Mean \\
\hline \multicolumn{17}{|c|}{$\begin{array}{l}\text { POSTMARITAL } \\
\text { CONCEPTION }\end{array}$} \\
\hline \multirow{2}{*}{$\begin{array}{l}\text { Non-manual } \\
\text { Skilled manual } \\
\text { Semi- and } \\
\text { unskilled } \\
\text { manual } \\
\text { All groups } \\
\text { SE } \\
\end{array}$} & $\begin{array}{r}10 \\
9\end{array}$ & $\begin{array}{r}-0 \cdot 8 \\
1 \cdot 3\end{array}$ & $\begin{array}{l}8 \\
6\end{array}$ & $\begin{array}{l}-4 \cdot 4 \\
-3 \cdot 7\end{array}$ & $\begin{array}{r}14 \\
7\end{array}$ & $\begin{array}{l}0.4 \\
5.3\end{array}$ & $\begin{array}{r}6 \\
17\end{array}$ & $\begin{array}{r}10 \cdot 3 \\
1 \cdot 1\end{array}$ & $\begin{array}{l}17- \\
19\end{array}$ & $\begin{array}{r}-0.5 \\
3.1\end{array}$ & $\begin{array}{r}7 \\
16\end{array}$ & $\begin{array}{r}3 \cdot 9 \\
3 \cdot 7\end{array}$ & $\begin{array}{r}4 \\
12\end{array}$ & $\begin{array}{l}-1 \cdot 5 \\
-1 \cdot 0\end{array}$ & $\begin{array}{l}135 \\
245\end{array}$ & $\begin{array}{l}1.9 \\
3.8\end{array}$ \\
\hline & $\begin{array}{l}14 \\
33\end{array}$ & $\begin{array}{ll}1.5 \\
0.8 \\
1.10 \\
\end{array}$ & 20 & $\begin{array}{c}-1.8 \\
-3.4 \\
0.93 \\
\end{array}$ & $\begin{array}{r}4 \\
25\end{array}$ & $\begin{array}{l}3 \cdot 5 \\
2 \cdot 3 \\
1 \cdot 10 \\
\end{array}$ & $\begin{array}{l}10 \\
33\end{array}$ & $\begin{array}{c}-0.2 \\
2.4 \\
0.84 \\
\end{array}$ & $\begin{array}{l}14 \\
50\end{array}$ & $\begin{array}{l}5 \cdot 2 \\
2.5 \\
0.79 \\
\end{array}$ & $\begin{array}{l}11 \\
34\end{array}$ & $\begin{array}{l}0.7 \\
2.8 \\
1.03 \\
\end{array}$ & $\frac{12}{28}$ & $\begin{array}{l}3.9 \\
1.0 \\
0.91 \\
\end{array}$ & $\begin{array}{l}234 \\
614\end{array}$ & $\begin{array}{l}3.5 \\
3.3 \\
0.24 \\
\end{array}$ \\
\hline \multirow{4}{*}{$\begin{array}{l}\text { PREMARITAL } \\
\text { CONCEPTION } \\
\text { Non-manual } \\
\text { Skilled manual } \\
\text { Semi- and } \\
\text { unskilled } \\
\text { manual } \\
\text { All groups } \\
\text { Difference } \\
\text { not available }\end{array}$} & & & & & & & & & & & & & & & & \\
\hline & & $-\overline{2 \cdot 5}$ & $\begin{array}{l}3 \\
5\end{array}$ & $\begin{array}{r}-2 \cdot 0 \\
-7.0\end{array}$ & $\begin{array}{l}4 \\
7\end{array}$ & $\begin{array}{l}6 \cdot 3 \\
1 \cdot 1\end{array}$ & $\begin{array}{l}1 \\
3\end{array}$ & $\begin{array}{l}-8 \cdot 0 \\
-0 \cdot 7\end{array}$ & 1 & $\begin{array}{r}0.0 \\
-6 \cdot 0\end{array}$ & 1 & $\begin{array}{l}i 0 \\
v \cdot 1\end{array}$ & $\begin{array}{l}3 \\
5\end{array}-$ & $\begin{array}{r}-4 \cdot 7 \\
-2 \cdot 0\end{array}$ & $\begin{array}{r}42 \\
105\end{array}$ & $\begin{array}{l}-1 \cdot 7 \\
-1 \cdot 4\end{array}$ \\
\hline & $\begin{array}{l}10 \\
18\end{array}$ & $\begin{array}{l}-1 \cdot 8 \\
-2 \cdot 1\end{array}$ & 99 & $\begin{array}{l}-3 \cdot 0 \\
-4 \cdot 0\end{array}$ & 11 & $\begin{array}{r}-1 \cdot 6 \\
0 \cdot 7\end{array}$ & $\begin{array}{r}6 \\
10\end{array}$ & $\begin{array}{l}-0.5 \\
-1.3\end{array}$ & $8=$ & $\begin{array}{l}-6 \cdot 3 \\
-5 \cdot 4\end{array}$ & $\begin{array}{r}8 \\
17\end{array}$ & $\begin{array}{l}3 \cdot 9 \\
2 \cdot 5\end{array}$ & $\begin{array}{r}9 \\
17\end{array}$ & $\begin{array}{r}0.0 \\
-1.4\end{array}$ & $\begin{array}{l}135 \\
282\end{array}$ & $\begin{array}{l}-0 \cdot 8 \\
-1 \cdot 2\end{array}$ \\
\hline & 21 & & 40 & & 37 & & 27 & & 37 & & 27 & & 35 & & 6 & \\
\hline
\end{tabular}

*A positive difference denotes a later week of first visit during the second pregnancy.

death is particularly interesting. Perhaps such a death, being a much more visible loss than a stillbirth, had a greater impact on the woman. The effect of prenatal hospitalisation on subsequent visiting is much more predictable because it is usually the direct result of problems detected during prenatal care.

For the PMC group, the mean differences $\left(D_{12}\right)$ clearly show that the PMCs compensated to the extent of beginning their care for the second pregnancy less than a week later than the legitimate group. This trend is not clearly evident among the complication groups, possibly because of small numbers and large variances. Only for neonatal deaths (and perhaps for stillbirths) is there evidence that PMC women compensated more than the controls in the second pregnancy-a finding consistent with the results for the legitimate conceptions.

The second difference $\left(D_{23}\right)$ is not presented in detail here because no notable trends were uncovered. All mean differences varied around zero, with a preponderance of small positive values, indicating that care began for the third pregnancy again at about the nineteenth or twentieth week of gestation. There were no clear effects on these estimates of socioeconomic status or complications of first pregnancy.

In order to summarise visiting patterns for all three pregnancies, the percentages showing each of three possible trends are presented in Table 5, including only those women for whom complete

Table 5 The percentage distribution of visiting trends over three consecutive pregnancies, for seven complications and controls, by status of the first conception

\begin{tabular}{|c|c|c|c|c|c|c|c|c|}
\hline \multirow[b]{2}{*}{ Trend } & \multicolumn{7}{|c|}{ COMPLICATIONS } & \multirow{2}{*}{$\frac{\text { CONTROLS }}{\text { (All years) }}$} \\
\hline & Stillbirth & $\begin{array}{l}\text { Neonatal } \\
\text { death }\end{array}$ & $\begin{array}{l}\text { Low birth } \\
\text { weight }\end{array}$ & $\begin{array}{l}\text { Caesarean } \\
\text { section }\end{array}$ & $\begin{array}{l}\text { Forceps } \\
\text { delivery }\end{array}$ & Long labour & $\begin{array}{l}\text { Prenatal } \\
\text { hospitalisation }\end{array}$ & \\
\hline $\begin{array}{l}\text { POSTMARIT } \\
\text { CONCEPTIOI } \\
\text { Earlier } \\
\text { Variable } \\
\text { Later } \\
\text { Total (100\%) } \\
\text { Not available }\end{array}$ & $\begin{array}{l}7 \cdot 4 \\
63 \cdot 0 \\
29 \cdot 6 \\
27 \\
16\end{array}$ & $\begin{array}{c}6 \cdot 7 \\
93 \cdot 3 \\
0 \cdot 0 \\
15 \\
16\end{array}$ & $\begin{array}{l}5 \cdot 0 \\
65 \cdot 0 \\
30 \cdot 0 \\
20 \\
24\end{array}$ & $\begin{array}{l}11 \cdot 5 \\
65 \cdot 4 \\
23 \cdot 1 \\
26 \\
27\end{array}$ & $\begin{array}{l}6 \cdot 5 \\
65 \cdot 2 \\
28 \cdot 3 \\
46 \\
39\end{array}$ & $\begin{array}{l}6 \cdot 3 \\
81 \cdot 3 \\
12 \cdot 5 \\
32 \\
20\end{array}$ & $\begin{array}{l}0 \cdot 0 \\
84 \cdot 6 \\
15 \cdot 4 \\
26 \\
25\end{array}$ & $\begin{array}{r}5 \cdot 1 \\
61 \cdot 0 \\
33 \cdot 9 \\
610 \\
10\end{array}$ \\
\hline \multicolumn{9}{|c|}{$\begin{array}{l}\text { PREMARITAL } \\
\text { CONCEPTION }\end{array}$} \\
\hline $\begin{array}{l}\text { Earlier } \\
\text { Variable } \\
\text { Later } \\
\text { Total (100\%) } \\
\text { Not available }\end{array}$ & $\begin{array}{l}25 \cdot 0 \\
56 \cdot 3 \\
18 \cdot 8 \\
16 \\
13\end{array}$ & $\begin{array}{l}28 \cdot 6 \\
64 \cdot 3 \\
7 \cdot 1 \\
14 \\
12\end{array}$ & $\begin{array}{l}15 \cdot 0 \\
60 \cdot 0 \\
25 \cdot 0 \\
20 \\
20\end{array}$ & $\begin{array}{c}14 \cdot 3 \\
85 \cdot 7 \\
0 \cdot 0 \\
7 \\
10\end{array}$ & $\begin{array}{l}36 \cdot 4 \\
54 \cdot 5 \\
9 \cdot 1 \\
11 \\
15\end{array}$ & $\begin{array}{l}28 \cdot 6 \\
57 \cdot 1 \\
14 \cdot 3 \\
14 \\
12\end{array}$ & $\begin{array}{l}28 \cdot 6 \\
64 \cdot 3 \\
7 \cdot 1 \\
14 \\
15\end{array}$ & $\begin{array}{c}15 \cdot 2 \\
71 \cdot 6 \\
13 \cdot 1 \\
282 \\
0\end{array}$ \\
\hline
\end{tabular}


data on the week of the first visit were available. Defining the mean week of first visit for each pregnancy as $V_{1}, V_{2}$, and $V_{3}$ respectively, the three trends were defined as follows:

(a) $V_{1}<V_{2}<V_{3}$ or $V_{1}<V_{2}<V_{3}$ (consistently later visiting)

(b) $\mathbf{V}_{1} \geqslant \mathbf{V}_{2}>\mathbf{V}_{3}$ or $\mathbf{V}_{1}>\mathbf{V}_{2} \geqslant \mathbf{V}_{3}$ (consistently earlier visiting)

(c) All other possibilities

(variable visiting)

The distribution of percentages over the three categories clearly confirms findings concerning the effects of PMC and complications of the first pregnancy on subsequent prenatal care (Table 4).

\section{Discussion}

It is clear from the findings that a premarital conception had only a temporary effect on the week of the first visit for prenatal care during the first pregnancy. Those with a postmarital first conception, and with no major problems during the first pregnancy and birth, delayed the first visit for the second pregnancy more than three weeks on average. This later start can be considered rational behaviour for mothers at demonstrably low risk. Moreover, according to the data presented, in most complication groups a substantial proportion still began prenatal care later the second time.

The only two complications for which notable differences in prenatal visiting patterns were found (neonatal death and prenatal hospitalisation) regardless of conception status deserve closer examination. Prenatal hospitalisation most frequently occurs because of chronic problems such as heart disease and diabetes, or problems detected during prenatal care, such as high blood pressure and toxaemia. Women with these conditions are most likely to benefit from the use of prenatal services in terms of detection and treatment. In this context, it can be considered rational behaviour for such women to make full use of prenatal care facilities, at least for the immediately subsequent pregnancy. It is highly unlikely however, that more prenatal care-especially earlier care-could prevent neonatal death which frequently results from prematurity. Certainly, the markedly earlier utilisation of prenatal services by this group of women deserves further investigation.

Another point of interest is that, during the two decades under study, the proportion of all first births which were PMC was known to be approximately one-third. Conception status was not a criterion of sample selection but was determined after the records had been selected for study. It is clear from Table 1 that the proportion of PMCs was approximately one-third for both the controls and the complication groups. Given that the PMC group had, on average, five weeks less prenatal care than the women with legitimate conceptions, there is, therefore, no evidence from these data that the PMC group was more likely to experience complications arising from the first pregnancy.

This raises an important policy question about whether women should be encouraged, indiscriminately, to begin prenatal care as soon as possible. Of the seven major complications considered in this study, only one, prenatal hospitalisation, represents a prenatal intervention. The remaining six are largely determined by the physical grade and nutritional state of the mother (Thompson, 1959) as well as by such ascribed social factors as age and height (Baird, 1952; Baird and Illsley, 1953; Illsley, 1967). Moreover, as has been demonstrated in this analysis and elsewhere, women of higher socioeconomic status tend to begin prenatal care earlier (Illsley, 1956b) and these women are known to have a better nutritional state and physical grade, so that the outcome is less likely to result in death or low weight of the baby (Baird et al., 1958). Because these factors are so inextricably confounded by self-selection, there is no way of assessing the real value of prenatal care from existing records. Yet numerous observational studies continue to provide apparently strong 'evidence' for the effectiveness of prenatal care (Butler and Bonham, 1963; YanKauer et al., 1953; Tokuhala et al., 1973), which is then used to justify further expansion of these services (Monahan and Spencer, 1962). Despite the proliferation of such studies we still await a carefully designed and conducted randomised controlled trial of prenatal medical care.

This is the final report in a series of studies on the utilisation of prenatal care funded by the Nuffield Provincial Hospitals Trust. We would like to thank Raymond Illsley (Institute for Medical Sociology, Aberdeen University), Ian MacGillivray (Department of Obstetrics and Gynaecology, Aberdeen University), and the staff of the Foresterhill Maternity Hospital.

Reprints from John B. McKinlay, Department of Sociology, Boston University.

\section{References}

Baird, D. (1952). Preventive medicine in obstetrics. New England Journal of Medicine, 246, 561-566.

Baird, D., and Illsley, R. (1953). Environment and childbearing. Proceedings of the Royal Society of Medicine, 46, 53-59.

Baird, D., Hytten, F., and Thompson, A. M. (1958). Age and human reproduction. Journal of Obstetrics and Gynaecology of the British Commonwealth, 60, 17-30. 
Butler, N. R., and Bonham, D. G. (1963). Perinatal Mortality. Livingstone: Edinburgh.

Gill, D. G., Illsley, R., and Koplik, L. H. (1970). Pregnancy in teenage girls. Social Science and Medicine, $3,549-574$.

Illsley, R. (1956a). Social Background to First Pregnancy. Doctoral dissertation, Aberdeen University (unpublished).

Illsley, R. (1956b). The duration of antenatal care. Medical Officer, 26, 107-111.

Illsley, R. (1967). The sociological study of reproduction and its outcome. In Childbearing-Its Social and Psychological Aspects. Edited by S. A. Richardson and A. F. Guttmacher. Williams and Wilkins: Baltimore.

MacMahon, B., Kovar, M. G., and Feldman, J. J. (1972). Infant Mortality Rates: Socioeconomic Factors.
Department of Health, Education and Welfare Publication No. (HSM) 72-1045: Series 22, No. 14. Public Health Service: Washington DC.

McKinlay, J. B. (1970). The new late comers for antenatal care. British Journal of Preventive and Social Medicine, 24, 52-57.

Monahan, H. B., and Spencer, E. C. (1962). Deterrents to prenatal care. Children, 9, 114-19.

Thompson, A. M. (1959). Maternal stature and reproductive efficiency. Eugenics Review, 51, 157-162.

Tokuhala, G. K., Digon, E., and Mann, L. (1973). Prenatal care and obstetric abnormalities. Journal of Chronic Diseases, 26, 163-185.

YanKauer, A., Goss, K. G., and Romeo, S. M. (1953). An evaluation of prenatal care and its relationship to social class and social disorganization. American Journal of Public Health, 43, 1001-1010. 